\title{
Low-density microarray analysis of TGF $\beta 1$-dependent cell cycle regulation in human breast adenocarcinoma MCF7 cell line
}

\author{
A. M. Dubrovska ${ }^{1}$, S. S. Souchelnytskyi ${ }^{2,3}$ \\ ${ }^{1}$ OncoRay-National Center for Radiation Research in Oncology, Medical Faculty Dresden \\ Carl Gustav Carus, Technische Universitat Dresden, Fetscherstr. 74/PF41 01307 Dresden, Germany \\ ${ }^{2}$ Department of Oncology-Pathology, Karolinska Institutet, Karolinska University Hospital \\ Solna, SE-17176, Stockholm, Sweden \\ ${ }^{3}$ Personalized Cancer Diagnostik \\ AB SE-75263, Uppsala, Sweden \\ Anna.Dubrovska@OncoRay.de
}

\begin{abstract}
Transforming growth factor $\beta 1$ (TGF $\beta 1$ ) is a growth regulator that has antiproliferative effects on a range of epithelial cells at the early stages and promoting tumorigenesis at the later stages of cancer progression. The molecular mechanisms of a duel role of TGFB1 in tumor growth regulation remain poorly understood. Aim. To analyze the TGFB1-dependent cell cycle regulation of tumorigenic breast epithelial cells. Methods. Our present study was designed to examine the regulatory effect of TGF 1 on the expression of a panel of 96 genes which are known to be critically involved in cell cycle regulation. GEArray $Q$ series Human Cell Cycle Gene Array was applied to profile the gene expression changes in MCF7 human breast adenocarcinoma cell line treated with $T G F \beta 1$. Results. The gene expression array data enabled us to reveal the molecular regulators that might connect TGFB1 signaling to the promoting of the tumor growth, e. g. retinoblastoma protein (pRB1), check-point kinase 2 (Chk2), breast cancer 1, early onset (BRCA1), DNA damage checkpoint protein RAD9, cyclin-dependent kinase 2 (CDK2), cyclin D1 (CCND1). Conclusions. The uncovering of the key signaling modules involved in TGFB1dependent signaling might provide an insight into the mechanisms of TGFB1-dependent tumor growth and can be beneficial for the development of novel therapeutic approaches.
\end{abstract}

Keywords: transforming growth factor $\beta 1$, human breast adenocarcinoma, MCF7 cell line, cell cycle regulation, microarray.

Introduction. Transforming growth factor $\beta 1$ (TGF $\beta 1)$ is a dimeric polypeptide growth factor with multiple physiological functions that has been first described as a stimulator of cellular tumorigenic transformation [1]. TGF $\beta 1$ initiates intracellular signaling through the binding to the specific receptors type I (TRRI) and type II (T $\beta R I I)$ on the cellular surface. TGF $\beta 1$ receptors contain serine/threonine kinase domains and form a heterotetramer composed of two TRRI:TRRII heterodimers complex upon TGF $\beta 1$ binding [2]. The formation of the ligand-receptor complex triggers a number of TGF $\beta 1$ -

(C) Institute of Molecular Biology and Genetics, NAS of Ukraine, 2014 dependent signaling pathways $[3,4]$. The TGF 31 -dependent signal transmission through the Smad transcriptional factors is considered to be the most important for TGF $\beta 1$ cell response. However, over the last decade the TGF $\beta 1$ - mediated activation of Smad-independent signal pathways has been also described. Among them, the Ras and mitogen-activated protein kinase (MAPK) pathways, p38, extracellular signal regulated kinases (ERK), cJun N-terminal kinase (JNK) have been shown to be activated in response to TGF $\beta 1$ [5]. Emergence of genomic and proteomic approaches advanced our understanding of the plasticity of TGF cellular response and provides a comprehensive overview of the role of 
TGF $\beta 1$ regulatory effect on the maintenance of cell and tissue homeostasis and functions. A number of novel TGF $\beta 1$ targets, which affect cell proliferation, death, DNA damage repair, differentiation, cytoskeleton rearrangement, and cellular metabolism have been identified in our previous reports [6-10].

A variety of studies have shown a dual role of TGF $\beta 1$ in the normal tissue maintenance and cancer [11]. TGF $\beta 1$ is a negative growth regulator that has antiproliferative effects on a range of epithelial cells at the early stages and promoting tumorigenesis at the later stages of cancer progression. Discovery of the selected signaling molecules has provided an insight into some molecular mechanisms behind this dual role of TGF $\beta 1$. However, a number of evidence suggests that an ability of cancer cells to overcome the growth inhibitory effects of TGF $\beta 1$ is a result of the functional changing a host of the intracellular signaling components.

Therefore, a large-scale genomic and proteomic analysis has to be employed to explain a switch in the TGF $\beta$-dependent cell response during tumor development. Our comparative analysis for some of the identified gene targets ( $c-a b l, C D K N 2 D, R A D 9$ ) has shown their distinct expression in the nontumorigenic epithelial cells MCF10A and human breast adenocarcinoma cells MCF7.

Expanding our knowledge of the differential employment of TGF $\beta 1$ signaling network by premalignant and tumor cells might contribute to our understanding of breast cancer development and can be potentially employed for therapeutic benefit. Our present study was designed to examine the TGF $\beta 1$ regulatory effect on the expression of 96 genes known to be critically involved in the cell cycle regulation.

Materials and methods. Cells and reagents. MCF7 cells were obtained from American Type Culture Collection (Manassas, USA), and cultured in DMEM supplemented with $10 \%$ of foetal bovine serum («Sigma-Aldrich», USA). TGF $\beta 1$ was added to the cells to final concentration of $5 \mathrm{ng} / \mathrm{ml}$. At $18 \mathrm{~h}$ after treatment, cells were lysed and protein extracts were analyzed by immunoblotting.

Sample preparation. Cells were lysed in $1 \%$ Triton $\mathrm{X}-100,40 \mathrm{mM}$ Tris-HCl, pH 8.0, 65 mM dithiothreitol (DTT), $1 \mathrm{mM}$ phenylmethylsulfonyl fluoride, $10 \mathrm{mM}$ aprotinin, and complete protease inhibitor cocktail («Ro- che Diagnostics», Germany). Cell lysates were clarified by centrifugation.

Immunobloting and immunoprecipitation. For immunoblotting, cell lysates were resolved on SDS/10 \% polyacrylamide gels and transferred onto Hybond $\mathrm{P}$ membranes («Amersham Biosciences», USA). Membranes were blocked with $5 \%(\mathrm{v} / \mathrm{v})$ BSA for one hour and then incubated with the primary antibody against DP-1 (K20), sc-610; Cyclin D3 (C-16), sc-182; RAD9 (M-389), sc-8324; Chk2 (A-12), sc-5278; p19 (M-167), sc-1063; c-Abl (24-11), sc-23; Smad-2 (YZ-13), sc-101153; pSmad-2 (Ser467), sc-101801; Actin (C-11), sc-1615-R («Santa Cruz Biotechnology Inc.», USA), with dilution as recommended by manufacturer followed by an incubation with HRP-conjugated secondary antibodies ( GE Heathcare», USA). The proteins were visualized using Western Blotting Luminol Reagents («Santa Cruz Biotechnology Inc., USA»). For immunoprecipitation, cell lysates were incubated with antibodies against target proteins and protein A-Sepharose beads («Sigma-Aldrich», USA) for $6 \mathrm{~h}$ at $40{ }^{\circ} \mathrm{C}$ with gentle agitation. Immunocomplexes bound to protein A-Sepharose beads were collected by centrifugation and washed 3 times in lysis buffer before being resolved by sodium dodecyl sulphate-polyacrylamide gel electrophoresis (SDS-PAGE).

Semiquantitative RT-PCR. Custom primer sets were designed using GeneFisher software. The following forward and reverse primer sets were synthesized: human $c$-abl (accession number M14752) forward, 5'-AGGATCAACACTGCTTCTG-3', reverse 5'-GATCTGAGTGGCCATGTAC-3';

human cyclin D3 (CCND3) (accession number M92287) -

forward, 5'-ACATATGAGGGGGAATAGTC-3', reverse 5'-TAGGAAAGACCTGTGTCAAC-3';

human cyclin-dependent kinase inhibitor 2D (CDK N2D) (accession number CR542158) -

forward 5'-CCGGTACCAGTCCAGTC-3', reverse 5'-AGCTCCAAGGGTGTGAG-3';

human cullin $4 A$ (cul4A) (accession number BC 008308) -

forward 5'-AGAAGGGAAGAAGGAATTCC-3', reverse 5'-TGGTACTGATTCGGATTGTC-3';

human meiotic recombination (Saccharomyces cerevisiae) 11 homolog B (MRE11B) (accession number AF022778) - 
forward 5'-CAGTGGTTACTTCTCTTTCC-3' reverse 5'-CTCTGCGGTTTGAAAGTAC-3';

human RAD9 (Schizosaccharomyces pombe) homo-

$\log (R A D 9)$ (accession number U53174) -

forward 5'-GGCTTTTTTAGACGGAGTC-3'

reverse 5'-CTCTTAAAGGGCCAAAGAAC-3';

human protein kinase Chk2 (RAD53) (accession number NM_007194) -

forward 5'-GCATATCCAGCTCCTCTAC-3', reverse 5'-GACTGATCATCTACAGTCAG-3';

human E2F-related transcription factor 1 (TFDP-1) (accession number L23959) -

forward 5'-GGTCTAATTGAAGCCAACG-3', reverse 5'-GCCATTAGCACGTTTAAGG-3';

human E2F-related transcription factor 2 (TFDP-2)

(accession number NM_006286) -

forward 5'-CTGGAGATAGAGAAGCAGAG-3', reverse 5'-GCATAACCCTTGGTTTACAC-3'.

Reverse transcription was performed with using of Super Script ${ }^{\mathrm{TM}}$ reverse transcriptase («Novagen», USA), as recommended by manufacturer. Relative gene expression was determined utilizing glyceraldehydes-3-phosphate dehydrogenase, GAPDH (accession number AF261085) as loading control. The following primer set for GAPDH was used:

forward 5'-CATAGACCAGAACCTTAGTC-3', reverse 5'-GACCTTCATGGAGAAATGC-3'.

Low-density microarray experiment was performed with RNA extracted from MCF7 cells, which were treated or non-treated with TGF $\beta 1$. RNA was extracted using a RNAsy mini kit («QIAGEN», USA), and RNA without any signs of degradation was used for analysis. Preparation of the probes (GEArray Probe synthesis kit, SuperArray Bioscience, USA), and hybridization with the membranes of Human Cell Cycle Gene array (HS001-4 GE array Q series; SuperArray Bioscience) were performed, as recommended by the manufacturer. After hybridization, the membranes were exposed in a FujiX 2000 PhosphorImager, and the acquired images were analysed using ScanAlyze software (http://rana.lbl. gov/EisenSoftware.htm).

Two-fold changes were considered as a threshold for significant TGF $\beta 1$-dependent changes in gene expression level.

Pathway analysis. Functional and signalling pathway analysis was done using Ingenuity Pathway Analy- sis, a commercial database for identifying networks and signalling pathways of interest in global genomic data. Dataset containing identified genes and corresponding expression values was uploaded into the Ingenuity Pathway Analysis application and TGF $\beta 1$ dependent network regulating cell growth and proliferation was generated. Fischer's exact test was used to calculate a p-value determining the network connectivity.

Luciferase reporter assay. Reporter assays with CAGA(12)-luc reporter was performed as described previously [12]. 293T cells were used, because they are responsive to TGF $\beta$ treatment and allow for efficient exogenous protein expression.

Results and discussion. TGF $\beta 1$ dependent expression of genes regulating cell proliferation in MCF7 cells. In the current study we explored changes in expression of genes involved in cell cycle regulation in MCF7 cells in response to TGF $\beta 1$ stimulation. To assess long-term changes in TGF $\beta 1$-dependent expression, MCF7 cells were analyzed after incubation with TGF $\beta 1$ for $18 \mathrm{~h}$ and compared with nontreated cells. Phosphorylation of Smad2 on C-terminal serine residue upon TGF $\beta 1$ treatment was used as an indicator for TGF $\beta 1$ signalling activation (Fig. 1, A). Human Cell Cycle Gene Array Q series has been applied to evaluate transcription level of 96 genes which are known to be regulators of cell cycle and response to DNA damage. We found that expression of 41 genes was altered at least twofold $(\mathrm{p}<0.05)$ after the treatment of the cells with TGF $\beta 1$ (Table 1). Among identified genes 17 were already known TGF $\beta 1$ target genes, $i$. e., transcription factors $D P-1, D P-2$, cyclins D1,D2, F, G1 and G2, cyclin dependent kinases $c d k 2, c d k 4, c d k 6, c d k 7$, cyclin-dependent kinase inhibitors $C D K N 1 C, C D K N 2 A, C D K N 2 B$, $C D K N 2 C, C D K N 2 D$, metallopeptidase inhibitor TIMP3 $[9,10]$. However, most of the differentially regulated genes have not been previously implicated in TGF $\beta 1$ signaling. Semi-quantitative RT-PCR and Western blotting analysis has been performed to validate the TGF $\beta 1$ dependent changes in the expression of some of the identified genes (Fig. 1, B, C). The obtained results were consistent with those from gene expression array supporting the validity of the microarray data. We revealed a distinct TGF 31 -dependent regulation of some of the identified genes (c-abl, CDKN2D, RAD9) in MCF10A nontumorigenic epithelial cells as compared to the MCF7 
$A$

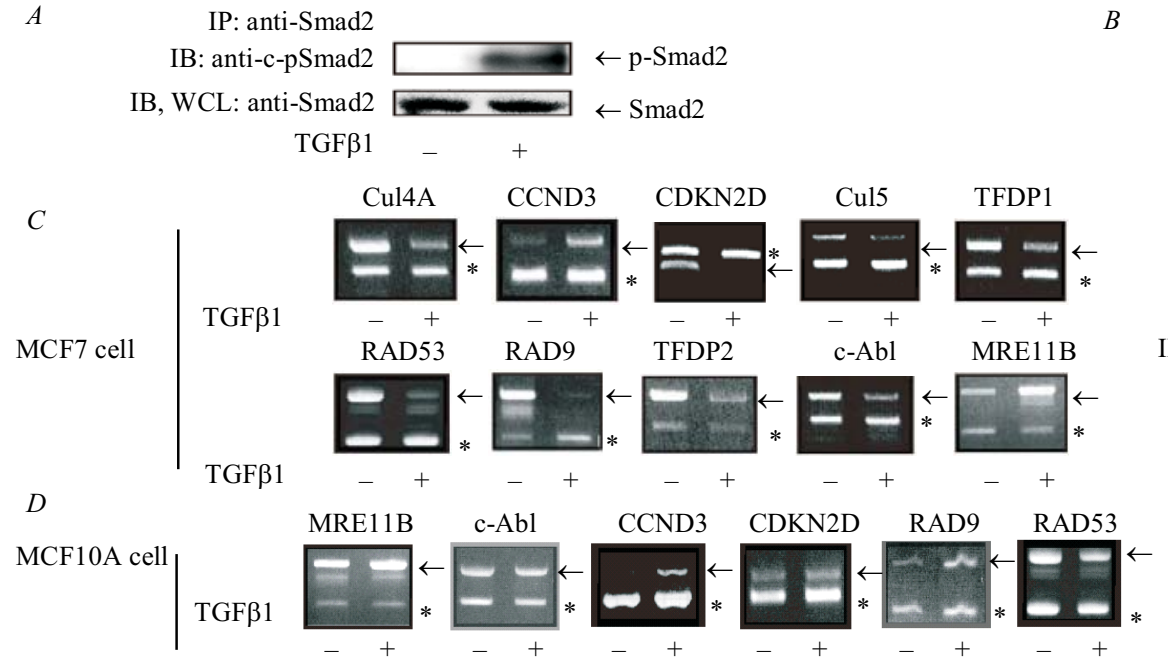

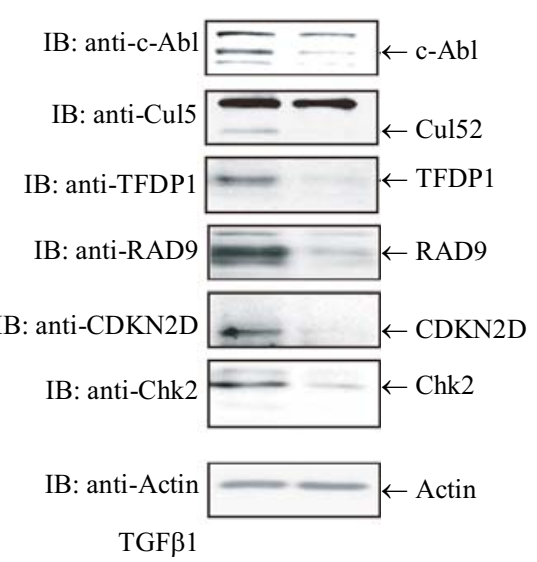

Fig. 1. Validation of microarray data: $A$ - phosphorylation of Smad-2 on C-terminal serine residue 467 upon TGF $\beta 1$ treatment was used as an indicator of the TGF $\beta 1$ signaling activation in human breast adenocarcinoma MCF7 cell line. Semi-quantitative RT-PCR and Western blotting analysis for some of the identified genes has been performed to validate the TGF $\beta 1$-dependent changes in gene expression $(B, C)$. Semi-quantitative RT-PCR analysis revealed a distinct TGF $\beta 1$ regulation for some of the identified genes (i. e. c-Abl, CDKN2D, RAD9) in MCF10A non-tumorigenic epithelial cells and MCF7 human breast adenocarcinoma cell line $(D)$

human breast adenocarcinoma cells that can be explained, at least in part, by switching the responsiveness of the mammary epithelial cells to TGF $\beta 1$ during tumor progression (Fig. 1, D).

Ingenuity Pathway analysis. To shed light on the signaling pathways contributing to the regulation of cell cycle by TGF $\beta 1$, all 41 genes differentially expressed in the TGF $\beta 1$ and untreated cells were subjected to pathway analysis by using Ingenuity Pathway Analysis. The Ingenuity Pathways Knowledge Base, a comprehensive knowledge base for identifying signalling networks for genes of human, rat and mouse was used to build signalling networks and make functional analysis of an entire dataset. Among the 96 genes that have been annotated as cell cycle regulators, expression of 41 genes was changed significantly upon TGF $\beta 1$ treatment in MCF7 human breast adenocarcinoma cell line (Table 1). All 41 overlaid genes (100 \%) were found in the pathway map. By focusing on these 41 genes, we constructed a TGF $\beta 1$ dependent cell cycle regulating network that included all known interaction between dataset genes. The signaling networks, which include TGF $\beta 1$-responsive genes are listed in Table 2. Upstream regulator analysis revealed Smad2, Smad3 and TGF $\beta 1$ as regulators of transcription in this gene network (Fig. 2, A). According to generated signaling network, we have identified a few signaling modules which might be considered as key transmitters of TGF $\beta$-signaling, which control cell cycle, e.g. estrogen receptor (ER), retinoblastoma protein (pRB1), checkpoint kinase 2 (Chk2), nuclear factor kappa-light-chain-enhancer of activated B cells (NFKB), breast cancer 1, early onset (BRCA1), platelet-derived growth factor (PDGF), cyclin-dependent kinase 2 (CDK2), cyclin D1 (CCND1). An overlapping of the canonical pathways involving identified genes revealed, among others, a preferential activation of the aryl hydrocarbon receptor (AhR) pathway, the growth arrest and DNA damage (GADD45) pathway and p53 signaling rout (Fig. 2, B).

Chk2 cooperates with Smad3 in transcriptional regulation. To explore the possible mechanism for the involvement of some of identified genes in TGF $\beta 1$-initiated signal transduction, we performed a luciferase reporter assay with TGF $\beta 1$-responsive CAGA(12)-luc reporter. This reporter contains multiple CAGA boxes which are specific binding site for Smad3 and Smad4 TGF 31 activated transcriptional factors. We used 293T cells because they are TGF $\beta 1$ responsive and allow high level of ectopic expression of target proteins. We observed that protein product of RAD53 gene-Chk2 kinase, which expression is found to be downregulated upon TGF 1 treatment, cooperated with Smad3 in activation of CAGA(12)-luc reporter (Fig. 3, A). To explore whether Chk2 and Smad proteins could form a complex, we 
Table 1

Genes involved in TGF 1 -dependent cell cycle regulation

\begin{tabular}{|c|c|c|c|c|c|}
\hline \multirow{2}{*}{$\begin{array}{c}\text { Accession } \\
\text { number }\end{array}$} & \multirow[b]{2}{*}{ Symbol } & \multirow[b]{2}{*}{ Description } & \multicolumn{3}{|c|}{ Gene expression (arbitrary units) } \\
\hline & & & Control & + TGF $\beta 1$ & $\begin{array}{c}\text { Fold } \\
\text { change }\end{array}$ \\
\hline X16416 & ABL1 & V-abl abelson murine leukemia viral oncogene homolog 1 & 137 & 65 & 2.122 \\
\hline NM_001160 & APAF1 & Apoptotic protease activating factor & 100 & 25 & 4.054 \\
\hline NM_000051 & ATM & Ataxia telangiectasia mutated (includes complementation groups A, C and D) & 101 & 46 & 2.200 \\
\hline L22474 & BAX & BCL2-associated X protein & 443 & 195 & 2.273 \\
\hline U68041 & BRCA1 & Breast cancer 1 , early onse & 1 & 67 & 66.670 \\
\hline NM_003914 & CCNA1 & Cyclin A1 & 10 & 1 & 10.052 \\
\hline X51688 & CCNA2 & Cyclin A & 23 & 322 & 14.227 \\
\hline M74091 & $\mathrm{CCNC}$ & G1/S-specific cyclin C & 275 & 110 & 2.505 \\
\hline X68452 & CCND2 & Cyclin D2 & 63 & 128 & 2.051 \\
\hline M90814 & CCND3 & Cyclin type D3 & 60 & 154 & 2.580 \\
\hline NM_004702 & CCNE2 & Cyclin E2 & 62 & 26 & 2.387 \\
\hline U17105 & $\mathrm{CCNF}$ & Cyclin F & 121 & 36 & 3.349 \\
\hline X77794 & CCNG1 & Cyclin G1 & 435 & 127 & 3.431 \\
\hline NM_001255 & $\mathrm{CDC} 20$ & $\mathrm{p} 55 \mathrm{cdc}$ & 80 & 375 & 4.704 \\
\hline NM_001256 & $\mathrm{CDC} 27$ & Cell division cycle 27 & 252 & 69 & 3.682 \\
\hline L22005 & $\mathrm{CDC} 34$ & Ubiquitin-conjugating enzyme,cell division cycle 34 & 302 & 93 & 3.264 \\
\hline AF015592 & CDC7L1 & CDC7 (cell division cycle 7, S. cerevisiae, homolog)-like 1 & 63 & 147 & 2.334 \\
\hline X61622 & CDK2 & Cyclin-dependent kinase 2 & 85 & 195 & 2.288 \\
\hline M14505 & CDK4 & Cyclin-dependent kinase 4 & 184 & 436 & 2.368 \\
\hline X66365 & CDK6 & Cyclin-dependent kinase 6 & 102 & 8 & 13.155 \\
\hline NM_001799 & CDK7 & $\begin{array}{l}\text { Cyclin-dependent kinase } 7 \text { (homolog of Xenopus MO15 cdk-activating } \\
\text { kinase) }\end{array}$ & 362 & 152 & 2.379 \\
\hline U22398 & CDKN1C & Cyclin-dependent kinase inhibitor 1C (p57, Kip2) & 50 & 101 & 2.033 \\
\hline U26727 & CDKN2A & Cyclin-dependent kinase inhibitor 2A (melanoma, p16, inhibits CDK4) & 36 & 111 & 3.095 \\
\hline L36844 & CDKN2B & Cyclin-dependent kinase inhibitor 2B (p15, inhibits CDK4) & 65 & 168 & 2.590 \\
\hline U17074 & $\mathrm{CDKN} 2 \mathrm{C}$ & Cyclin-dependent kinase inhibitor 2C (p18, inhibits CDK4) & 147 & 11 & 13.691 \\
\hline U40343 & CDKN2D & Cyclin-dependent kinase inhibitor 2D (p19, inhibits CDK4) & 213 & 57 & 3.770 \\
\hline AF077188 & CUL4A & Cullin 4A & 329 & 91 & 3.621 \\
\hline AB014595 & CUL4B & Cullin 4B & 425 & 135 & 3.147 \\
\hline AF059292 & E2F6 & E2F transcription factor 6 & 346 & 58 & 5.945 \\
\hline U74613 & FOXM1 & Human putative M phase phosphoprotein 2 (MPP2) mRNA & 208 & 81 & 2.571 \\
\hline D38073 & MCM3 & Minichromosome maintenance deficient (S. cerevisiae) 3 & 162 & 461 & 2.841 \\
\hline
\end{tabular}


Conclusion of Table 1

\begin{tabular}{|c|c|c|c|c|c|}
\hline \multirow{2}{*}{$\begin{array}{l}\text { Accession } \\
\text { number }\end{array}$} & \multirow[b]{2}{*}{ Symbol } & \multirow[b]{2}{*}{ Description } & \multicolumn{3}{|c|}{ Gene expression (arbitrary units) } \\
\hline & & & Control & $+\mathrm{TGF} \beta 1$ & $\begin{array}{l}\text { Fold } \\
\text { change }\end{array}$ \\
\hline AF022778 & MRE11B & Meiotic recombination (S. cerevisiae) 11 homolog B & 191 & 532 & 2.783 \\
\hline AF058696 & NBS1 & Nijmegen breakage syndrome 1 (nibrin) & 254 & 50 & 5.084 \\
\hline NM_007194 & RAD53 & Protein kinase Chk2 & 113 & 1 & 113.178 \\
\hline U53174 & RAD9 & RAD9 (S. pombe) homolog & 260 & 1 & 260.101 \\
\hline M15400 & RB1 & Retinoblastoma 1 (including osteosarcoma) & 328 & 30 & 10.902 \\
\hline NM_002895 & RBL1 & Retinoblastoma-like 1 (p107) & 214 & 55 & 3.924 \\
\hline U33761 & SKP2 & Human cyclin A/CDK2-associated p45 (Skp2) & 201 & 629 & 3.132 \\
\hline L23959 & TFDP1 & Homo sapiens E2F-related transcription factor (DP-1) & 286 & 14 & 20.828 \\
\hline NM_006286 & TFDP2 & Transcription factor Dp-2 (E2F dimerization partner 2) & 299 & 32 & 9.324 \\
\hline
\end{tabular}

Table 2

Molecular networks which include TGF $\beta$-responsive genes

\begin{tabular}{l|c|c|c}
\hline Molecules in network & Score & $\begin{array}{c}\text { Focus } \\
\text { molecules }\end{array}$ & Top diseases and functions \\
\hline
\end{tabular}

APC (complex), CAK, CCNA1, CCNA2, CCND3, CCNE2, Cdc2, CDC7, CDC20, Cdk, CDK4, CDK6, CDK2-CyclinE, CDK4/6, CDK4/6-Cyclin D1, CDKN1C, CDKN2B, CDKN2C, CDKN2D, Cyclin A, Cyclin $43 \quad 18$

Cell Cycle, Cellular Growth and ProliA/Cdk2, Cyclin D,CyclinD1/cdk4, Cyclin E, E2f, E2F6, ERK1/2, FOXM1, INK4, Rb, RBL1, RNA polymerase III, SKP2, TFDP1, TFDP2

14-3-3, Akt, alcohol group acceptor phosphotransferase, APAF1, ATM, ATM/ATR, Basc, BAX, BRCA1, caspase, CCNC, CCND2, CCNG1, CDK2, CDK7, CDK2-Cyclin D1,CDK4-Cyclin D2, CDKN2A, CHEK2, Ctbp, Cyclin B, cyclin h/cdk7, HoloRNA polymerase II, Hsp70, MCM3, Mre11, MRE11A, MRN, NBN, RAD9A, Raf, RB1, RNA polymerase II, TFIIH, TIP60

ABL1, ADRB, Ap1, calpain, CCND1, CCNF, CDC27, Collage n type I, Creb, estrogen receptor, Fc-gamma receptor, Focal adhesion kinase, Hdac, Hedgehog, Histone h4, Hsp27, Hsp90, Immunoglobulin, Integrin, Laminin, LDL, Mapk, Mek, NFkB(complex), P38 MAPK, p70 S6k, Pdgf (complex), PDGF BB, PP2A, Smad, STAT5a/b, Tgf beta, thymidine kinase, TIMP3, TSH

26s Proteasome, AMPK, ARHGAP1, AURKC, BCR (complex), Calmodulin, CD3, CDC34, Cg,CUL4A, CUL4B, cytochromeC, ERK, FSH, Gamma tubulin, Gsk3, HISTONE, Histone H1,Histone h3, IgG, Igm, Insulin, Interferon alpha, Jnk, PI3K (complex), Pka, Pkc(s), POLH, PPP1R3A, Rac, Ras, Sapk, Ube3, Ubiquitin, Vegf performed a co-immunoprecipitation assay of Smad3 cotransfected with Chk2. We revealed that Smad3 interacts with Chk2, and these Smad3/Chk2 complexes have been formed even in the absence of treatment with TGF $\beta 1$ ligand (Fig. 3, B). Therefore, we found that Smad3 and the protein product of RAD53 gene Chk2 kinase exerted a cooperative effect in activation of the TGF $\beta 1 /$
Smad3-responsive transcription. This transcription regulation may be an example of a feedback mechanism, which includes TGF $\beta 1$-dependent inhibition of RAD53 gene expression and simultaneous restrain of Smad3dependent transcriptional regulation. In contrast, we found that other checkpoint Rad proteins Rad9, which has been also identified in the gene expression array 


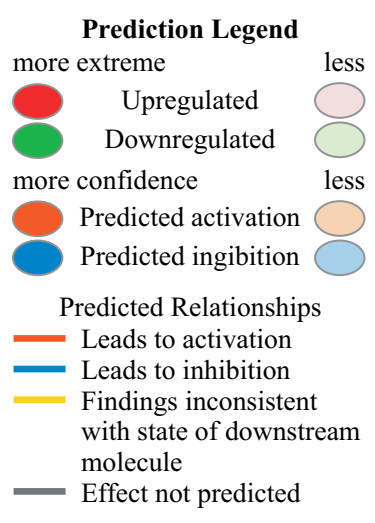

Symbol Entrez Gene Name:

ATM ataxia telangiectasia mutated;

BAX BCL2-associated $X$ protein;

CCNA1 cyclin A1;

CCNA2 cyclin A2;

CCND1 cyclin D1;

CCND2 cyclin D2;

CCND3 cyclin D3;

CCNE2 cyclin E2;

CDK2 cyclin-dependent kinase 2;

CDK4 cyclin-dependent kinase 4;

CDK6 cyclin-dependent kinase 6;

CDKN2A cyclin-dependent kinase inhibitor 2A;

CHEK2 checkpoint kinase 2;

RB1 retinoblastoma 1;

TFDP1 transcription factor Dp-1
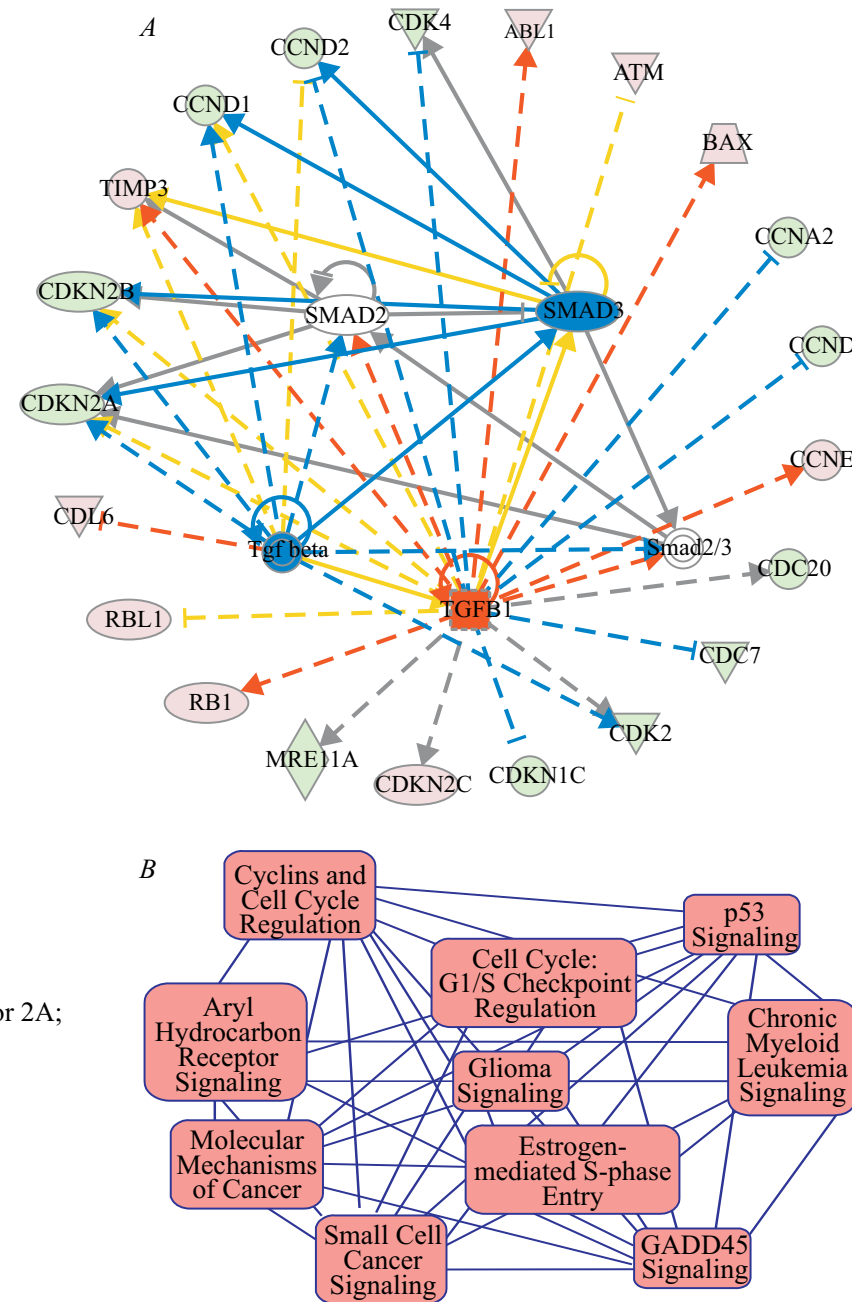

Fig. 2. The Ingenuity Pathways Knowledge analysis of the signalling networks. 41 genes, those expression was changed significantly upon TGF $\beta 1$ treatment in MCF7 2 human breast adenocarcinoma cell line were used to construct a TGF $\beta 1$-dependent cell cycle regulating network. Upstream regulator analysis revealed Smad2, Smad3 and TGF $\beta 1$ as transcriptional regulators involved in gene regulatory network $(A)$; An overlapping of the canonical pathways involving identified genes revealed, among others, a preferential activation of the aryl hydrocarbon receptor (AhR) pathway, the growth arrest and DNA damage (GADD45) pathway and $\mathrm{p} 53$ signaling rout. The genes involved in the AhR signaling are shown in the left panel (B) APAF1 apoptotic peptidase activating factor 1 experiment, did not show any effect on Smad3 dependent transcription and is not involved in the interaction with Smad3 protein (Fig. 4, $A, B$ ).

In our previous study we have showed that TGF $\beta 1$ is counteracting the BRCA1-dependent DNA repair process [13] and is implicated in the maintenance of genome stability via regulation of RAD51 expression [14]. Another report suggests a functional link between TGF $\beta 1$ signaling and the ATM-mediated genotoxic stress response [15]. In this study we have also observed that, in addition to Chk2 and RAD9, TGF $\beta 1$ is effecting an expression a few other proteins implicated in DNA repair, cell cycle checkpoint control, apoptosis and maintenance of the genomic integrity including c-Abl, ATM, MRE11B (Meiotic recombination (S. cerevisiae) 11 homolog B). Downregulation of the expression of c-Abl, ATM, RAD9 and RAD53 genes in malignant cells upon TGF $\beta 1$ treatment suggests an additional mechanism of increasing genomic instability, which can potentially contribute to the cancer development.

TGF $\beta 1$ is a ubiquitous cytokine that switches its roles from tumor suppressor to tumor promoter as the tumor progresses through the multiple mechanisms, including mutational inactivation of TGF $\beta 1$ receptors and Smad proteins, loss of selective cytostatic gene response, and activating tumor promoter genes [1-5]). Given the integral role of TGF $\beta 1$ in the tumor progression, it follows that TGF $\beta 1$ signaling offers an attractive target for cancer therapy.

Techniques such as microarray hybridization allow a big-scale analysis of genes implicated in TGF $\beta 1$ dependent signal transduction. In conjunction with pathways analysis, transcriptional profiling might be beneficial for identification of the key signal transmitters and assessment of a functional load of the distinct signaling components. 


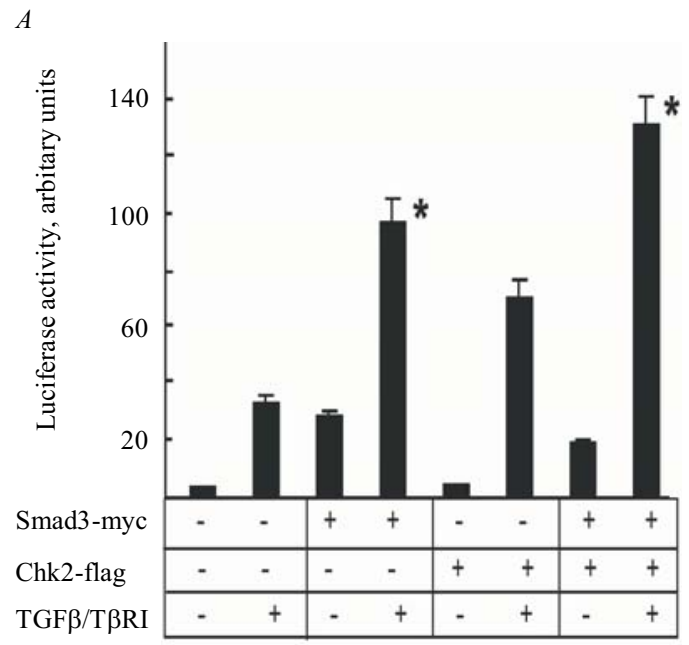

$B$

IB, anti-Smad3 IB: anti-flag

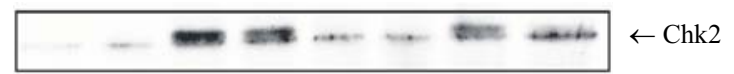

IB, WCL:anti-flag anti-myc

Chk2-flag

Smad3-myc

TGF $\beta / T \beta R I$

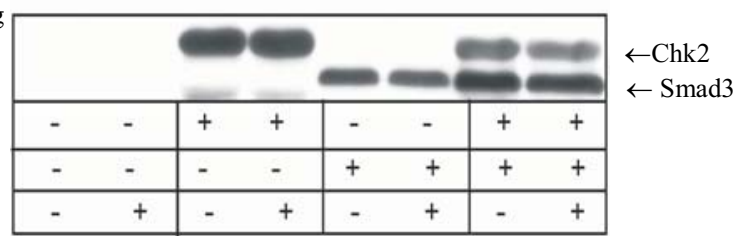

Fig. 3. Chk2 kinase cooperates with Smad3 in activation of CAGA(12)-luc reporter: $A-293 \mathrm{~T}$ cells were transfected with TGF $\beta 1$-responsive CAGA(12)-luc reporter and DNA constructs expressing Chk2-flag and Smad3-myc proteins (cell were treated with TGF $31(0,5 \mathrm{ng} / \mathrm{ml})$ for $18 \mathrm{~h}$, and luciferase activity has been measured; a representative experiment out of three performed, is shown. ${ }^{*} \mathrm{p}<0.05$ ); $B-$ to explore whether Chk2 and Smad3 proteins form a complex, we performed a co-immunoprecipitation assay of the Smad3-myc and Chk2-flag proteins which were overexpressed in $293 \mathrm{~T}$ cells

$A$

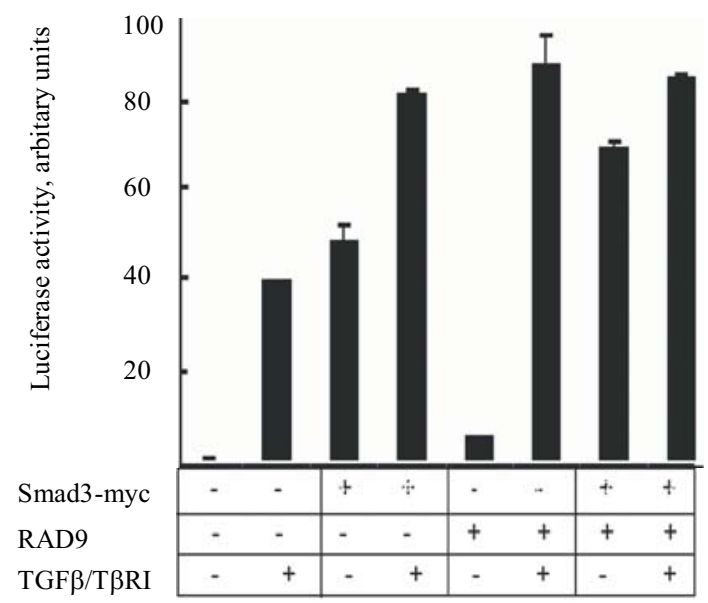

$B$

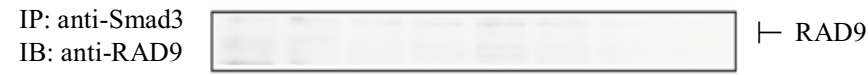

IB, WCL: anti-RAD9

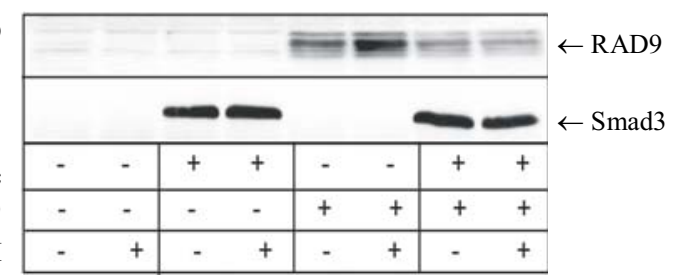

Fig. 4. RAD9 does not participate in regulation of Smad3-dependent transcription: $A-293 \mathrm{~T}$ cells were transfected with TGF $\beta 1$-responsive CAGA(12)-luc reporter and DNA constructs expressing RAD9 and Smad3-myc proteins (cell were treated with TGF $\beta 1(0,5 \mathrm{ng} / \mathrm{ml})$ for $18 \mathrm{~h}$, and luciferase activity has been measured); $B$ - coimmunoprecipitation assay of cotransfected Smad3-myc and RAD9 has indicated that RAD9 is not involved in the interaction with $\operatorname{Smad} 3$ protein

To identify the key cell cycle regulators of TGF 1 signaling we performed low-density microarray analysis of human breast adenocarcinoma MCF7 cell line treated or non-treated with TGF $\beta 1$. Among the 96 genes that have been annotated as cell cycle regulators, expression of 41 genes was changed significantly upon TGF $\beta 1$ treatment in MCF7 human breast adenocarcinoma cell line. Some of identified genes have been reported before as TGF $\beta$-responsive targets (transcription factors $D P-1, D P$ -
2, cyclins $C C N D 1, C C N F, C C N G 1$ and $C C N G 2, C D K 2$, $C D K 4, C D K 6, C D K 7$, cyclin-dependent kinase inhibitors $C D K I 1 C, C D K I 2 A, C D K I 2 B, C D K I 2 C, C D K I 2 D$ ) [9]. However, for the most of the differentially regulated genes identified in this study, little information is known on their role in the TGF $\beta 1$-directed cell cycle regulation.

A lot of recent data suggest that regulation of the cell cycle depends on protein degradation by the ubiqui- 
tin-proteasome machinery. On the other hand, the TGF $\beta /$ Smads-dependent signaling is known to be regulated by reversed ubiquitination and protein degradation process $[16,17]$. The ubiquitination reaction requires the coordination of various classes of functional modules, and cullin complexes play an important role in the regulation of protein degradation through their ubiquitin-ligase activity. Human genome encodes five different cullins - Cul1, Cul2, Cul3, Cul4, and Cul5. All of them can compose the catalytic core of the different cullin-based ubiquitin-ligase, and, therefore, target a large number of substrates for ubiquitin-dependent degradation, including p27, p21, p57, p130, Cyclin E, E2F-1, Cdk9, c-Myc, which are involved in regulation of cell proliferation and apoptosis [18]. We found that expression of two cullins $4 \mathrm{~A}$ and $4 \mathrm{~B}$, as well as ubiquitin-conjugating enzyme, CDC34 were suppressed by TGF $\beta 1$, suggesting that proteosomal degradation is one of the mechanisms trough which TGF $\beta 1$ can regulate the cell cycle machinery.

Our previous proteomics studies indicate that TGF $\beta 1$ can regulate transcription machinery via controlling gene expression and through the post-translation modification mechanisms $[17,19]$. In this study we also observed that some of the identified TGF $\beta 1$-responsive proteins are involved in the regulation of gene transcription, such as E2F6 (E2F transcription factor 6), TFDP1 (Homo sapiens E2F-related transcription factor, DP-1), TFDP2 (Transcription factor DP-2, E2F dimerization partner 2). Recent studies suggest that transcriptional repression of $c-m y c$ protooncogene is critical for the manifestation of TGF $\beta 1$-dependent cytostatic program. The $c-m y c$ transcription is repressed through the E2F4/ 5, DP-1 and Smad3 complexes [20, 21]. Transcriptional factor c-Myc is one of the key regulators of cell growth, metabolism and apoptosis [22]. TGFß1-dependent downregulation of $D P-1$ gene in MCF7 cells can contribute to the restraining of TGF $\beta 1$-dependent transcription repression of $c-m y c$. At the same time the $\mathrm{E} 2 \mathrm{~F} /$ DP heteromeric transcription factor family is a very well characterized $\mathrm{pRb}$ interactor [23]. A lot of studies have demonstrated that transcriptional activity of E2F proteins is linked to poor clinical outcome in a wide-variety of different types of human cancers [24-27]. They have an oncogenic function, which has been attributed to the ability of the E2F proteins to induce S-phase of cell cycle through the transcriptional regulation of $c y c$ - lins $A$ and $E$, proto-oncogenes $c-m y c$ and $c-m y b$, genes important for DNA replication, and $R b$ family genes ( $\mathrm{Rb}$ and $\mathrm{p} 107)[23,28]$. On the other hand, E2F proteins are known to be the inductors of p53-dependent apoptotic pathway. Plasticity of E2F dependent functional outcomes can provide the fine-tuned mechanism of TGF $\beta 1$-dependent regulation of cell growth and inhibition.

Activities of cyclin-dependent kinase (CDKs) and their activating subunits, the cyclins are critical for the function of cell cycle machinery $[29,30]$. The pattern of cyclin expression defines the cell position within the cell cycle. Cyclin-dependent kinase inhibitors (CDKIs) bind and inhibit cyclin-associated kinase and serve as negative regulators of the cell cycle machinery. We have found that TGF $\beta 1$ is regulating a number of cyclin genes (cyclin D1,D2,D3,E2,F, G1), cyclin-dependent kinase $(C D K 2,4,6,7)$, cyclin-dependent kinase inhibitors $(C D K I 1 C, \mathrm{p} 57 ; C D K N 2 A, \mathrm{p} 16 ; C D K N 2 B, \mathrm{p} 15$; $C D K N 2 C, \mathrm{p} 18 ; C D K N 2 D, \mathrm{p} 19)$ suggesting that TGF $\beta$ might regulate the cell cycle at the different stages and by the various molecular mechanisms. Some of these cell cycle regulatory genes have been previously reported as TGF $\beta$-responsive genomic targets. Previous investigation of the human umbilical vein endothelial cells (HU VEC) infected with TRRI-expressing adenovirus has shown that transcription a number of cell cycle regulators can be affected by TGF $\beta$ signaling activation, including cyclin-dependent kinases $C D K 2, C D K 4, C D K 6$, $C D K 7$; cyclins $C C N D 2, C C N D 3, C C N F, C C N G 1$; cyclin-dependent kinase inhibitors $C D K N 2 B, C D K N 2 C$, $C D K N 2 D$ ) [7]. Some of these genes exhibited expression profiles similar to those stimulated by TGF $\beta 1$ in our study, including $C C N D 3, C D K 2$ (unregulated) and $C C N F, C C N G 1, C D K N 2 D$ (downregulated). However, some of identified genes have the different manner of TGF 31 -dependent regulation for breast adenocarcinoma and nonmalignant human endothelial cells (CDKN2D, CDK4, CDK6, CDK7, CDKN2B, CDKN2C), suggesting the duel manner of TGF 1 1-dependent cell growth regulation in normal and cancer cells. To check a possibility of differential regulation of some other TGF $\beta$ responsive genes in normal and malignant cells, we have performed semi-quantitative RT-PCR analysis for MRE11B, c-Abl, CCND3, CDKN2D, RAD9, RAD53 gene expression in MCF10A non-tumorigenic epithelial 
cells and MCF7 human breast adenocarcinoma cell line. We found distinct TGF $\beta 1$-dependent regulation of $c-A b l, C D K N 2 D$ and $R A D 9$ genes, suggesting that these genes can potentially contribute to the switching the responsiveness of the normal and tumor epithelial cells to TGFß1.

In order to search the TGF $\beta 1$-dependent signaling modules connected to the regulation of cell cycle, we examined the identified genes in known pathways network with using of the Ingenuity Pathways Knowledge Base. An overlapping of the canonical pathways involving identified genes revealed, among others, a preferential activation of the aryl hydrocarbon receptor (AhR) pathway.

Recent study demonstrated that glioma pathogenesis involves altered AhR regulation of the TGF $\beta /$ Smad pathway suggesting AhR as a promising target for the treatment of human tumors associated with pathological TGF $\beta$ activity [31]. Nevertheless, the role of AhR for the TGF $\beta$-driven breast tumor development remains unknown. Finding of these signaling compounds might provide an insight into mechanism of TGF $\beta 1$-dependent cell cycle control.

Taken together our study suggest that investigation of the TGF $\beta$-dependent gene expression regulation in breast cancer cells and their normal counterparts might contribute to the identification of molecular mechanisms critical for cancer development and can potentially be applied for the development of new therapeutic approaches.

Аналіз TGF $\beta$-залежної регуляції клітинного циклу в клітинах лінії MCF7 раку молочної залози людини з використанням мікромасивів 3 низькою щільністю

А. М. Дубровська, С. С. Сушельницький

Резюме

Трансформуючий ростовий фактор $\beta 1$ (ТGFß1) є важливим регулятором клітинного росту. Він чинить антипроліферативну дію на низку епітеліальних клітин на ранніх стадіях транс- формаціі і при изьоу сприяє появі онкогенності на пізніших ста-діях розвитку раку. Молекулярні механізми подвійної ролі TGFß1 у регуляиї росту пухлини лишаються маловивченими. Мета. Аналіз TGFß1-залежної регуляиії клітинного ичиклу ракових клітин молочної залози. Методи. Вплив ТGFß1 на експресію 96 генів-регуляторів клітинного циклу - вивчали на клітинах раку молочної залози людини MCF7, які обробляли TGFß1. Рівень експресї̈ генів до i після обробки аналізували методом GEArray Q ПЦР. Результати. Дані ПЛР дозволили виявити регулятори клітинного ичиклу, які можуть бути залучені до ТGFß1-залежної стимуляції пухлин- ного росту, з-поміж них гени ретинобластоми PRB1, кінази Chk2, маркера раку молочної залози BRCA1, регулятора репарачії ДНК RAD9, ичилін-залежної кінази CDK2, ичикліну CCND1. Висновки. Вивчення ключових модулів ТGFß1-залежного клітинного сигналінгу, який контролює клітинний цикл, може допомогти в розумінні подвійної ролі изього фактора в регулячії пухлинного росту та сприятиме розробиі нових терапевтичних підходів.

Ключові слова: трансформуючий фактор росту $\beta 1$, рак молочної залози людини, клітинна лінія MCF7, регуляція клітинного циклу, мікромасиви.

Анализ TGF $\beta$-зависимой регуляции клеточного цикла в клетках линии MCF7 рака молочной железы человека с использованием микромассивов низкой плотности

\section{А. М. Дубровская, С. С. Сушельницкий}

Резюме

Трансформирующий ростовой фактор $\beta 1$ (ТGFß1) является важным регулятором клеточного роста. Он оказывает анти- пролиферативное действие на ряд эпителиальных клеток на ранних стадиях трансформации и при этом способствует появлению онкогенности на более поздних стадиях развития рака. Молекулярные механизмы двойной роли TGFß1 в регуляции роста опухоли остаются малоизученными. Цель. Анализ ТGFß1-зависимой регуляции клеточного цикла раковых клеток молочной железы. Методы. Влияние TGFß1 на экспрессию 96 генов - регуляторов клеточного цикла - изучали на клетках рака молочной железы человека MCF-7, которые обрабатывали TGFß1. Уровень экспрессии генов до и после обработки анализировали методом GEArray Q ПЦР. Результаты. Данные ПЦР позволили выявить регуляторы клеточного цикла, которые могут быть вовлечены в ТGFß1зависимую стимуляцию опухолевого роста, среди них гены ретинобластомы PRB1, киназы Chk2, маркера рака молочной железы $B R C A 1$, регулятора репарачии ДНК RAD9, циклин-зависимой киназы CDK2, ичклина CCND1. Выводы. Изучение ключевых модулей TGFß1-зависимого клеточного сигналинга, контролирующего клеточный цикл, может помочь в понимании двойной роли этого фактора в регуляции опухолевого роста и будет способствовать разработке новых терапевтических подходов.

Ключевые слова: трансформирующий фактор роста $\beta 1$, рак молочной железы человека, клеточная линия $M C F 7$, регуляция клеточного цикла, микромассивы.

\section{REFERENCES}

1. Kloen P, Jennings CL, Gebhardt MC, Springfield DS, Mankin $H J$. Expression of transforming growth factor-beta (TGF-beta) receptors, TGF-beta 1 and TGF-beta 2 production and autocrine growth control in osteosarcoma cells. Int J Cancer. 1994; 58 (3): 440-5.

2. Huang T, David L, Mendoza V, Yang Y, Villarreal M, De K, Sun $L$, Fang X, Lopez-Casillas $F$, Wrana JL, Hinck AP. TGF- $\beta$ signalling is mediated by two autonomously functioning T $\beta \mathrm{RI}$ : T $\beta$ RII pairs. EMBO J. 2011; 30(7):1263-76.

3. Moustakas A, Souchelnytskyi S, Heldin CH. Smad regulation in TGF-beta signal transduction. J Cell Sci. 2001; 114(Pt 24): 4359-69.

4. Wakefield LM, Piek E, Bottinger EP. TGF-beta signaling in mammary gland development and tumorigenesis. J Mammary Gland Biol Neoplasia. 2001; 6(1):67-82. 
5. Derynck R, Zhang YE. Smad-dependent and Smad-independent pathways in TGF-beta family signalling. Nature. 2003; 425 (6958):577-84.

6. Souchelnytskyi S. Proteomics of TGF-beta signaling and its impact on breast cancer. Expert Rev Proteomics. 2005; 2(6): 925-35.

7. Iwahana H, Yakymovych I, Dubrovska A, Hellman U, Souchelnytskyi $S$. Glycoproteome profiling of transforming growth factor-beta (TGFbeta) signaling: nonglycosylated cell death-inducing DFF-like effector A inhibits TGFbeta1-dependent apoptosis. Proteomics. 2006; 6(23):6168-80.

8. Zakharchenko O, Cojoc M, Dubrovska A, Souchelnytskyi S. A ro-

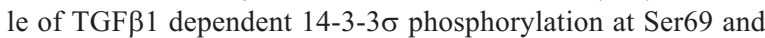
Ser74 in the regulation of gene transcription, stemness and radioresistance. PLoS One. 2013; 8(5):e65163.

9. Ota T, Fujii M, Sugizaki T, Ishii M, Miyazawa K, Aburatani H, Miyazono $K$. Targets of transcriptional regulation by two distinct type I receptors for transforming growth factor-beta in human umbilical vein endothelial cells. J Cell Physiol. 2002; 193 (3):299-318.

10. Qureshi HY, Ricci G, Zafarullah M. Smad signaling pathway is a pivotal component of tissue inhibitor of metalloproteinases-3 regulation by transforming growth factor beta in human chondrocytes. Biochim Biophys Acta. 2008; 1783(9):1605-12.

11. Bachman KE, Park BH. Duel nature of TGF-beta signaling: tumor suppressor vs. tumor promoter. Curr Opin Oncol. 2005; 17 (1):49-54

12. Yakymovych I, Ten Dijke P, Heldin CH, Souchelnytskyi S. Regulation of Smad signaling by protein kinase C. FASEB J. 2001; 15(3):553-5.

13. Dubrovska A, Kanamoto T, Lomnytska M, Heldin CH, Volodko $N$, Souchelnytskyi S. TGFbeta1/Smad3 counteracts BRCA1-dependent repair of DNA damage. Oncogene. 2005; 24(14): 2289-97.

14. Kanamoto T, Hellman U, Heldin CH, Souchelnytskyi S. Functional proteomics of transforming growth factor-beta1-stimulated Mv1Lu epithelial cells: Rad51 as a target of TGFbeta1-dependent regulation of DNA repair. EMBOJ. 2002; 21(5): 1219-30.

15. Kirshner J, Jobling MF, Pajares MJ, Ravani SA, Glick AB, Lavin MJ, Koslov S, Shiloh Y, Barcellos-Hoff $M H$. Inhibition of transforming growth factor-beta1 signaling attenuates ataxia telangiectasia mutated activity in response to genotoxic stress. Cancer Res. 2006; 66(22):10861-9.

16. Wicks SJ, Grocott T, Haros K, Maillard M, ten Dijke P, Chantry $A$. Reversible ubiquitination regulates the Smad/TGF-beta signalling pathway. Biochem Soc Trans. 2006; 34(Pt 5):761-3.

17. Ohashi N, Yamamoto T, Uchida C, Togawa A, Fukasawa H, Fujigaki Y, Suzuki S, Kitagawa K, Hattori T, Oda T, Hayashi H, Hishida A, Kitagawa $M$. Transcriptional induction of Smurf2 ubiquitin ligase by TGF-beta. FEBS Lett. 2005; 579(12):2557-63.

18. Nakayama KI, Nakayama K. Regulation of the cell cycle by SCFtype ubiquitin ligases. Semin Cell Dev Biol. 2005; 16(3):323-33.
19. Stasyk T, Dubrovska A, Lomnytska M, Yakymovych I, Wernstedt $C$, Heldin CH, Hellman U, Souchelnytskyi S. Phosphoproteome profiling of transforming growth factor (TGF)-beta signaling: abrogation of TGFbeta1-dependent phosphorylation of transcription factor-II-I (TFII-I) enhances cooperation of TFII-I and Smad3 in transcription. Mol Biol Cell. 2005; 16(10):4765-80.

20. Chen CR, Kang Y, Siegel PM, Massague J. E2F4/5 and p107 as Smad cofactors linking the TGFbeta receptor to $c-m y c$ repression. Cell. 2002; 110(1):19-32

21. Frederick JP, Liberati NT, Waddell DS, Shi Y, Wang XF. Transforming growth factor beta-mediated transcriptional repression of c-myc is dependent on direct binding of Smad3 to a novel repressive Smad binding element. Mol Cell Biol. 2004; 24(6): 2546-59.

22. Xu J, Chen Y, Olopade OI. MYC and breast cancer. Genes Cancer. 2010;1(6):629-40.

23. Johnson DG, Schneider-Broussard R. Role of E2F in cell cycle control and cancer. Front Biosci. 1998; 3:d447-8.

24. Zeng X, Yin F, Liu X, Xu J, Xu Y, Huang J, Nan Y, Qiu X. Upregulation of E2F transcription factor 3 is associated with poor prognosis in hepatocellular carcinoma. Oncol Rep. 2014; 31(3): 1139-46.

25. Lasham A, Samuel W, Cao H, Patel R, Mehta R, Stern JL, Reid G, Woolley AG, Miller LD, Black MA, Shelling AN, Print CG, Braithwaite $A W$. YB-1, the E2F pathway, and regulation of tumor cell growth. J Natl Cancer Inst. 2012; 104(2):133-46.

26. Rakha EA, Pinder SE, Paish EC, Robertson JF, Ellis IO. Expression of E2F-4 in invasive breast carcinomas is associated with poor prognosis. J Pathol. 2004; 203(3):754-61.

27. Molenaar JJ, Koster J, Ebus ME, van Sluis P, Westerhout EM de Preter K, Gisselsson D, Ora I, Speleman F, Caron HN, Versteeg $R$. Copy number defects of G1-cell cycle genes in neuroblastoma are frequent and correlate with high expression of E2F target genes and a poor prognosis. Genes Chromosomes Cancer. 2012; 51(1):10-9.

28. Fang $Z H$, Han $Z C$. The transcription factor E2F: a crucial switch in the control of homeostasis and tumorigenesis. Histol Histopathol. 2006; 21(4):403-13.

29. Schwartz GK, Shah MA. Targeting the cell cycle: a new approach to cancer therapy. J Clin Oncol. 2005; 23(36):9408-21.

30. Golias $C H$, Charalabopoulos A, Charalabopoulos K. Cell proliferation and cell cycle control: a mini review. Int J Clin Pract. 2004; 58(12):1134-41.

31. Gramatzki D, Pantazis G, Schittenhelm J, Tabatabai G, Kohle C, Wick W, Schwarz M, Weller M, Tritschler I. Aryl hydrocarbon receptor inhibition downregulates the TGF-beta/Smad pathway in human glioblastoma cells. Oncogene. 2009; 28(28):2593-605.

Received 15.01.14 